\title{
PROJECTED RADIONUCLIDE INVENTORIES OF DWPF GLASS FROM CURRENT WASTE AT TIME OF PRODUCTION (U)
}

by

\author{
M. J. Plodinec
}

Westinghouse Savannah River Company

Savannah River Site

Aiken, South Carolina 29808

This paper was prepared in connection with work done under the above contract number with the U. S.

Department of Energy. By acceptance of this paper, the publisher and/or recipient acknowledges the U. S. Government's right to retain a nonexclusive, royalty-free license in and to any copyright covering this paper, along with the right to reproduce and to authorize others to reproduce all or part of the copyrighted paper.

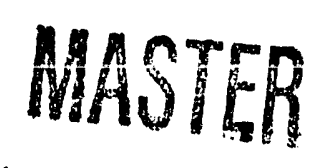




\section{DISCLAIMER}

This report was prepared as an account of work sponsored by an agency of the United States.Government. Neither the United States Government nor any agency thereof, nor any of their employees, makes any warranty, express or implied, or assumes any legal liability or responsibility for the accuracy, completeness, or usefulness of any information, apparatus, product, or process disclosed, or represents that its use would not infringe privately owned rights. Reference herein to any specific commercial product, process, or service by trade name, trademark, manufacturer, or otherwise does not necessarily constitute or imply its endorsement, recommendation, or favoring by the United States Government or any agency thereof. The views and opinions of authors expressed herein do not necessarily state or reflect those of the United States Government or any agency thereof.

This report has been reproduced directly from the best available copy.

Available to DOE and DOE contractors from the Office of Scientific and Technical Information, P.O. Box 62, Oak Ridge, TN 37831; prices available from (615) 576-8401, FTS 626-8401.

Available to the public from the National Technical Information Service, U.S. Department of Commerce, 5285 Port Royal Rd., Springtield, VA 22161. 


\section{PROJTCTYF RADIONUCIIDP INVYHNTORISS OF DKPF GIASS

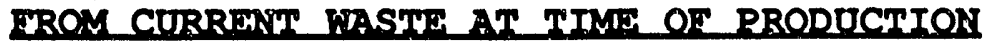

\section{INTTRODUCTION AND SUMMARY}

The Waste Acceptance Preliminary Specifications (WAPS) ${ }^{1}$ require that the DWPF estimate the inventory of long-lived radionuclides present in the waste glass, and report the values in the waste Form Qualification Report. In this report, consexvative (biased high) estimates of the radionuclide inventory of glass produced from waste currently in the Tank Farm are provided. In most cases, these calculated values compare favorably with actual data. In those cases where the agreement is not good, the values reported here are conservative.

\section{SPECIFICATION}

The WAPS specification for radionuclide inventory projections (Specification 1.2 .1 ) requires that "The producer shall report the estimated inventory of
radionuclides (in Curies) that have half-lives longer
than 10 years and that are or will be present in concen-
trations greater than 0.05 percent of the total radioac-
tive inventory for each waste type at any time up to
1100 years after production. The producer shall also
report the upper limit of all radionuclides for any can-
istered waste form. These estimates shall be indexed to
the year 2025 . The inventory at year 3125 shall also be
provided.

The producer shall provide in the WQR estimates of the total quantities of individual radionuclides to be shipped to the repository and the estimated error in the values. The producer shall also provide in the WQR estimates of the inventories for each waste type and the estimated error."1

The DWPF will provide the required estimates for each of the sludge batches of current waste which will be fed to the DWPF (a "waste type," in terms of the specificacion), as well as for future waste generation." In this report, estimates are developed for the first four sludge batches to the DWPE, at time of production.

\section{RADTONUCITDES TO BE RFPORTHD}

The DWPF curie balance ${ }^{3}$ (which defines the radionuclide inventory of the design-basis glass) has been used to define the set of radionuclides to be reported to the repository (Table 1). All of the radionuclides in this set have a half-life $>10$ years, and 
constitute at least 0.01 \& (on a curie basis) of the radionuclide inventory of the design-basis glass at the time of production, or at some later time up to 1100 years after production. This fixed set of species was chosen because of the difficulty of determining which radionuclides will constitute 0.05 of either a single canister, or even the entire ensemble of canisters, in the time frame of interest. 4 Choosing a more stringent limit $(0.01 \%)$ assures that all radionuclides that must be reported are included.

TABIE 1

\section{RADIONOCLIDES TO BF RFPORTHDA}

$\begin{array}{ll}\mathrm{Ni}-59 & \mathrm{Th}-230 \\ \mathrm{Ni}-63 & \mathrm{U}-234 \\ \mathrm{Se}-79 & \mathrm{U}-238 \\ \mathrm{Sr}-90 & \mathrm{~Np}-237 \\ \mathrm{Zr}-93 & \mathrm{Pu}-238 \\ \mathrm{Nb}-93 \mathrm{~m} & \mathrm{Pu}-239 \\ \mathrm{Tc}-99 & \mathrm{Pu}-240 \\ \mathrm{Pd}-107 & \mathrm{Pu}-241 \\ \mathrm{Sn}-126 & \mathrm{Pu}-242 \\ \mathrm{Cs}-135 & \mathrm{Am}-241 \\ \mathrm{Cs}-137 & \mathrm{Am}-243 \\ \mathrm{Sm}-151 & \mathrm{Cm}-244\end{array}$

* Includes all radionuclides with half-lives greater than 10 years, and with concentration greater than $0.01 \%$ of the total curie inventory of the design-basis glass at any time up to 1100 years.

\section{SOURCFS OF DATA}

The radionuclide inventory projections are based on several sources of data. These include:

- DOE's Integrated Data Base. ${ }^{5}$ This document details waste generation, waste immobilization, and waste storage plans at SRS, as 
well as data from other DOE sites. It does not include many of the radionuclides of interest, but is the primary source for Sr-90 and Cs-137, which make up the majority of the activity in the waste (It should be noted that it also contains values for Tc-99; however, these are known to be in error by a factor of at least 10, and more likely 20. These have been corrected in the most recent submittal for this report.). The Cs-137, Ba-137m, Sr-90, and Y-90 values out to the year 2009 are collected in Table 2, as are summary values from the Integrated Data Base.

TABLE 2

DATA FROM INTHFRATFD DATA BASF, 1991

\begin{tabular}{|c|c|c|c|c|}
\hline YEAR & $\underline{S} \mathbf{r}-90$ & $Y-90$ & $\mathrm{Cs}-137$ & $\mathrm{Ba}-137 \mathrm{~m}$ \\
\hline $1993^{\dagger}$ & 13.1 & 13.1 & 123.4 & 113.6 \\
\hline 1994 & 12.0 & 12.0 & 67.9 & 62.5 \\
\hline 1995 & 11.7 & 11.7 & 69.0 & 63.4 \\
\hline 1996 & 79.3 & 79.3 & 47.4 & 43.6 \\
\hline 1997 & 89.5 & 89.5 & 36.8 & 33.3 \\
\hline 1998 & 75.3 & 75.3 & 45.9 & 42.3 \\
\hline 1999 & 73.9 & 73.9 & 42.6 & 39.2 \\
\hline 2000 & 63.4 & 63.4 & 28.2 & 25.9 \\
\hline 2001 & 57.8 & 57.8 & 23.6 & 21.7 \\
\hline 2002 & 49.7 & 49.7 & 20.0 & 18.4 \\
\hline 2003 & 44.9 & 44.9 & 17.6 & 16.2 \\
\hline 2004 & 41.4 & 41.4 & 15.9 & 14.6 \\
\hline 2005 & 43.3 & 43.3 & 16.4 & 15.1 \\
\hline 2006 & 45.2 & 45.2 & 16.8 & 15.4 \\
\hline 2007 & 42.7 & 42.7 & 15.5 & 14.3 \\
\hline 2008 & 37.4 & 37.4 & 19.5 & 17.9 \\
\hline 2009 & 66.9 & 66.9 & 26.0 & 24.0 \\
\hline
\end{tabular}

* $0.625 \mathrm{~m}^{3}$ of glass in each canister

† Assumed DWPF startup in September, 1993

- The DWPF curie balance. ${ }^{3}$ As noted above, this was the basis for determining which radionuclides to report. The curie balance provided the basis for biological shielding, process cooling, and environmental release containment requirements for the design of the DWPF. The curie balance (which describes the radionuclide inventory of the design-basis glass) represents an upper bound in terms of the dose rate, and the heat generation rate, expected from DWPF canistered waste forms. The amount of each of the radionuclides 
which would be reported in the Production Records for a canister containing the design-basis glass is shown in Table 3.

TABLE 3

RADIONUCLIDE INVENTORY OF THE DWPF DESIGN-BASIS GLASS (5-year-old sludge, 15-year-01d supernate)

Badionuclide

$\mathrm{Ni}-59$

$\mathrm{Ni}-63$

$\mathrm{Se}-79$

Sr -90

Zr-93

$\mathrm{Nb}-93 \mathrm{~m}$

Ta-99

Pd-107

sn-126

Cs -135

Cs -1.37

Sin-151

Th-230

$\mathrm{U}-234$

$\mathrm{U}-238$

Np-237

Pu-238

$\mathrm{Pu}-239$

$\mathrm{Pu}-240$

Pu-241

$\mathrm{Pu}-242$

Am-241

Am-243

Cm-244

TOTAL
Inventory (Ci/canister)

$2.39 \mathrm{E}-02$

$2.97 \mathrm{E}+00$

1. $70 \mathrm{E}-01$

$4.82 \mathrm{E}+04$

1. $12 \mathrm{E}+00$

$1.12 \mathrm{E}+00$

$3.07 E+00$

1. $47 \mathrm{E}-02$

4. $38 \mathrm{E}-01$

9. $92 \mathrm{E}-02$

$4.33 \mathrm{E}+04$

2. $39 E+02$

2. $00 \mathrm{E}-06$

3. $42 \mathrm{E}-02$

1. $05 \mathrm{E}-02$

8. 86E-03

1. $48 \mathrm{E}+03$

1. $29 \mathrm{E}+01$

8. $67 \mathrm{E}+00$

1. $66 \mathrm{E}+03$

1. $22 \mathrm{E}-02$

1. $10 \mathrm{E}+01$

5. 79E-03

$1.07 \mathrm{E}+02$

$2.35 \mathrm{E}+05$ 
- Projections of the compositions of the glasses which will be made from the first four batches of sludge to be processed in the Tank Farm. ${ }^{6-9}$ Although these are primarily projections of the chemical compositions of the individual batches, they also contain information about some of the radionuclides of interest taken from analyses and from waste generation flowsheets. The data in the first portion of Table 4 represent the mass flow of the particular species into the canister as a part of the glass. The mass fraction in the glass of that species is thus the mass flow of the species divided by the total mass flow of glass. Thie last two parts of the Table contain estimates of the $U$ and $\mathrm{Pu}$ speciation of each batch, based primarily on waste generation flowsheets from SRS' Separations areas.

TABIE 4

RTPORTABI.E RADIOACTIVI COMPONFNTS IN DWPF PROJFCTIONS

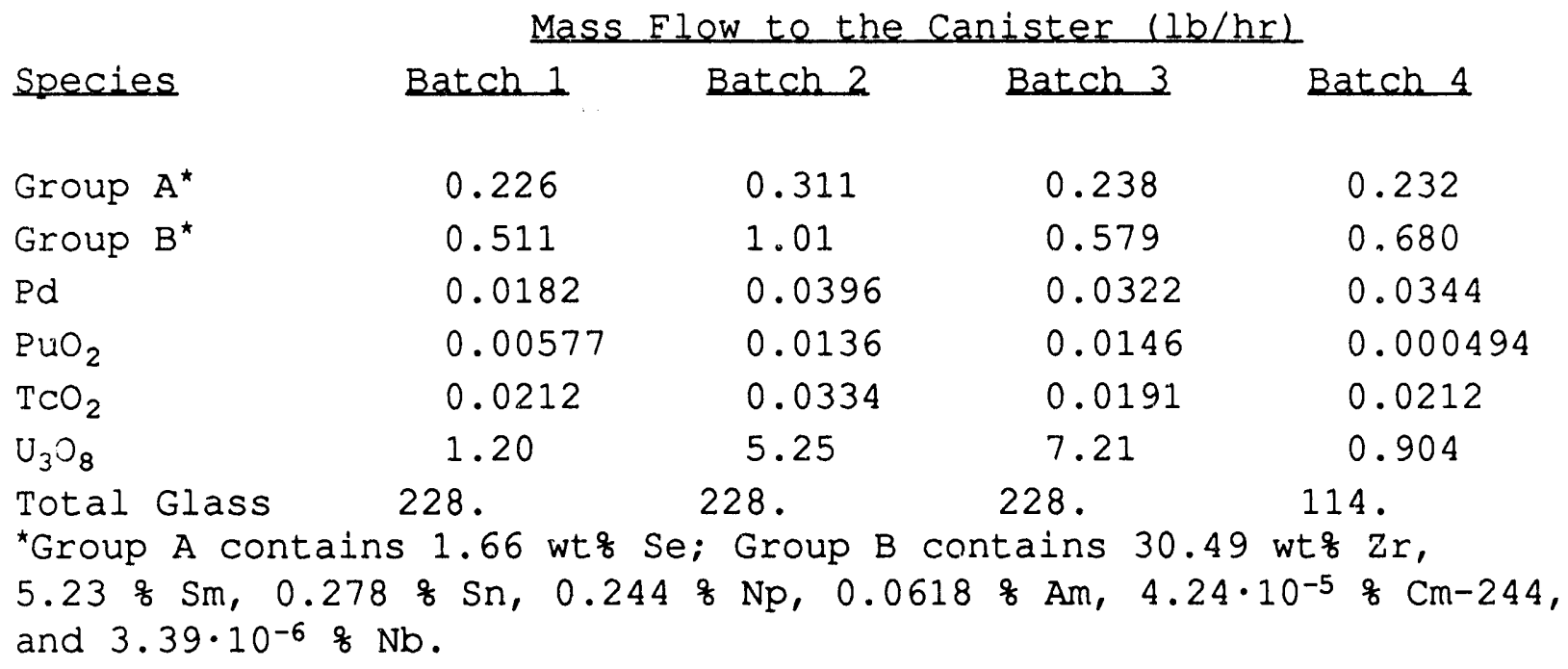

Radionuclide

$\mathrm{U}-233$

$\mathrm{U}-235$

$\mathrm{U}-238$

Radionuclide

$\mathrm{Pu}-238$

Pu-239

$\mathrm{Pu}-240$

Pu-241

$\mathrm{Pu}-242$
Speciation of Uranium (wt 8$)$

$$
0.01
$$

0.01

0.01

0.13

0.44

0.56

1.24

99.23

99.55

99.43

98.63

Speciation of Plutonium (wt 8 )

$\begin{array}{rrrc}6.03 & 9.46 & 5.66 & 17.27 \\ 88.01 & 85.49 & 88.00 & 82.73 \\ 4.08 & 3.82 & 4.58 & 0.0 \\ 0.19 & 0.62 & 1.64 & 0.0 \\ 1.69 & 0.61 & 0.12 & 0.0\end{array}$


- The assumed processing schedule for each sludge batch, 10 and estimates of canister production. 11 The assumed processing schedule is needed so that the values in Table 2 can be assigned to the appropriate sludge batcin. The estimates of canister production are primarily of importance in determining the total amount of radionuclides contained in the glass produced from each sludge batch. Based on the information in reference 11, it is assumed that 910 canisters will be produced from Batch 1, 987 canisters from Batch 2, 1002 canisters from Batch 3, and 751 canisters from Batch 4.

- In addition, new analytical data (primarily from ICP-MS analyses of actual sludges, which will be reported in a supporting document for Volume 4 of the Waste Form Qualification Report) for some of the trace radionuclides have also been considered in making the estimates. Of particular importance are the values for $\mathrm{Pu}-238$ (41 Ci/canister), $\mathrm{Pu}-239$ (3.4 Ci/canister), $\mathrm{Am}-241$ (6.4 Ci/ canister), and $\mathrm{Cm}-244$ (3.7 Ci/canister) for waste which will constitute approximately one-third of Batch 1 (This waste is currently stored in Tank 51, but originally came from the waste tanks identified in references 10 and 11). Although not used directly, these values have been compared to the projections, to evaluate the projections' reasonableness.

\section{PROJECTIONS OF INVINTORIES OF BATCHIS 1 THROOGH 4}

The projected radionuclide inventories at time of production for the glass which will be produced from sludge Batches 1 - 4 are shown in Table 5. In general, these were calculated by using the most representative value available. When it was not possible to decide on this basis, the values for the design-basis glass were used. In these cases, the projected values are probably conservative (higher) compared to actual values. The details of these calculations for the inventory in a canister of each type of glass are discussed below.

- The Ni-59 and Ni-63 contents of each type of glass were calculated from the ratio of their contents in the design-basis glass to that of $\mathrm{Am}-243$. Since all are activation products, it was assumed that these ratios should be approximately constant for each type of glass. The calculated amount of $\mathrm{Ni}-59$ (or $\mathrm{Ni}-63$ ) in a particular type of glass is this ratio ([Ni-59 or -63$] /[\mathrm{Am}-243]$ for the design-basis glass) multiplied by the Am-243 content of that type of glass.

- Se-79 was determined from the values in Table 4. The mass fraction of $\mathrm{Se}$ in each type of glass was calculated from the mass flow of "Group A" for the glass divided by 228. 1b/hr, and then multiplied by 0.0166 (the weight fraction of se in Group A). This value was then multiplied by $1.68 \cdot 10^{6} \mathrm{~g} /$ canister $(=3710 \mathrm{lb})$, to determine the mass of $\mathrm{Se}$ in a canister. Since the se value reflects several isotopes (Se-79, Se-80, Se-82), the mass of Se-79 was calculated by 
Mass of Se-79 per canister $=\mathrm{m}(\mathrm{Se})_{\mathrm{t}} \cdot(\mathrm{FY}(\mathrm{Se}-79) \cdot 79) /$

$$
[(\mathrm{EY}(\mathrm{Se}-79) \cdot 79)+(\mathrm{FY}(\mathrm{Se}-80) \cdot 80)+(\mathrm{FY}(\mathrm{Se}-82) \cdot 82)]
$$

where $m(S e)_{t}=$ total mass of $S e$ in the canister, and FY signifies the fission yield of the particular isotope.12 The mass of Se-79 per canister (in $g$ ) was then multiplied by the specific activity of $\mathrm{Se}-79.13$

- The values for $S r-90$ and Cs-137 were calculated from the values in Table 2, and the time required to process each sludge Batch in reference 10. These values are believed to be the most representative of those for the actual waste. The values in Table 2 were averaged for each batch, and then multiplied by 0.625 (to convert from $\mathrm{Ci} / \mathrm{m}^{3}$ to $\mathrm{Ci} /$ canister).

- Zr-93, Nb-93m, Sn-126, Np-237, Am-241, and Am-243 were calculated from the values in Table 4 . All are members of Group $B$. The mass of each per canister for each type of glass was determined in a manner similar to that described for se-79. For each, the mass was then multiplied by the specific activity ${ }^{13}$ to obtain the inventory in curies/canister.

The measured amount of Am-241 in the Tank 51 samples is less than the projected Batch 1 value by roughly 15\%. In view of the crudeness of the calculation, this agreement is quite good.

- The inventory of Tc-99 was calculated from the amounts of $\mathrm{TCO}_{2}$ for each of the projected chemical compositions in Table 4. The amount of $\mathrm{TCO}_{2}$ in a canister of each type of glass was converted to Tc-99 by multiplying by the ratio of the molecular weights of the metal and the metal oxide. These were then converted to curies/ canister by multiplying by the specific activity. It should be noted that there are also values for TC-99 in the Integrated Data Base. ${ }^{5}$ These values should not be used for any purpose, because of serious inaccuracies.

- The Pd-107 contents at time of production were calculated from the values of $\mathrm{Pd}$ in Table 4 . The mass flow values for $\mathrm{Pd}$ were converted to mass per canister, in the same manner as described for Se-79. Since the Pd value reflects several isotopes (Pd-105, $\mathrm{Pd}-106, \mathrm{Pd}-107, \mathrm{Pd}-108, \mathrm{Pd}-110)$, the fraction of $\mathrm{Pd}-107$ was calculated by

Mass of $\mathrm{Pd}-107$ per canister $=\mathrm{m}(\mathrm{Pd})_{\mathrm{t}} \cdot(\mathrm{FY}(\mathrm{Pd}-107) \cdot 107) /$

$$
\begin{aligned}
{[(F Y(P d-105) \cdot 105)+} & (F Y(P d-106) \cdot 106)+(F Y(P d-107) \cdot 107)+ \\
& (F Y(P d-108) \cdot 108)+(F Y(P d-110) \cdot 110)]
\end{aligned}
$$

where $\mathrm{m}(\mathrm{Pd})_{t}=$ total mass of $\mathrm{Pd}$ in the canister, and $\mathrm{FY}$ signifies the fission yield of the particular isotope. ${ }^{12}$ The mass of Pd-107 per canister (in $g$ ) was then multiplied by the specific activity 
of $\mathrm{Pd}-107.13$

- The Cs-135 content at time of production was calculated as the ratio of the Cs-135 and Cs-137 contents of the design-basis glass, multiplied by the Cs-137 content of each type of glass. No other information is available for Cs-135; analyses of initial precipitate feed to the DWPF will be used to update these estimates.

- The Sm-151 contents at time of production were calculated from the values for Group $B$ and $\mathrm{Sm}$ in Table 4. The mass flow values for Sm were converted to mass per canister, in the same manner as described for $S e$. Since the $S m$ value reflects several isotopes (Sm-147, Sm-149, Sm-151, Sm-152, Sm-154), the fraction of Sm-151 was calculated by

Mass of Sm-151 per canister $=m(S m)_{t} \cdot(F Y(S m-151) \cdot 151) /$

$$
[(F Y(S m-147) \cdot 147)+(F Y(S m-149) \cdot 149)+(F Y(S m-151) \cdot 151)+
$$

$(F Y(S m-152) \cdot 152)+(E Y(S m-154) \cdot 154)]$

where $\mathrm{m}(\mathrm{Sm})_{t}=$ total mass of $\mathrm{Sm}$ in the canister, and FY signifies the fission yield of the particular isotope. ${ }^{12}$ The mass of Sm-151 per canister (in $g$ ) was then multiplied by the specific activity of $\mathrm{Sm}-151,13$ to obtain the value in Table 5 .

- The amounts of U-234 in the as-produced glasses were assumed to be proportional to the amount of uranium in each glass composition in Table 4. The mass flow values for $\mathrm{J}_{3} \mathrm{O}_{8}$ were converted to the mass of $U$ in each canister in the same manner as described for Tc99. The U-234 content of each glass at time of production was then calculated as the U-234 content of the design-basis glass multiplied by the ratio of uranium in the two glasses. The values in Table 5 are much larger than those which would result from use of the speciation data in Table 4. There are no other data available for comparison with this data.

- The Th-230 contents were determined by multiplying the curiecontent of U-234 in each type of giass by the ratio of the Th-230 and U-234 activities in the design-basis glass (Table 3 ).

- The amounts of U-238 in the as-produced glasses were assumed to be proportional to the mass flow of uranium in each type of glass (Table 4). The mass flow values for $\mathrm{U}_{3} \mathrm{O}_{8}$ were converted to the mass of $U$ in each canister in the same manner as described for TC99. This mass was then converted to ci/canister, using the specific activity.

- The values for Pu-238 and Pu-239 were both estimated based on the values in Table 4. The total amount of $\mathrm{Pu}$ in a canister of each type of glass was calculated from the values in Table 4, in the same manner as described for TC-99. The isotopic mass fractions of $\mathrm{Pu}-238$ and $\mathrm{Pu}-239$ (from the last portion of Table 4) were then multiplied by the total amount of $\mathrm{Pu}$ in each type of glass to 
obtain the mass of Pu-238 (or Pu-239) in each canister. These mass values were then multiplied by the specific activities of the isotopes ${ }^{13}$ to obtain curies of the isotope in each canister. The values in Table 5 compare favorably with the Tank 51 values cited earlier.

- For Pu-240, Pu-241, and Pu-242, the amount (in curies) of each in a canister of glass of Batch $i$ was calculated by

$$
R(P u-X)_{i}=[R(P u-X) / R(P u-239)]_{D B} \cdot R(P u-239)_{i}
$$

where $R$ denotes activity of the species in the parentheses in $\mathrm{Ci} /$ canister; Pu-X denotes Pu-240, Pu-241 or Pu-242; DB means the design-basis glass; and $i$ refers to Batch $i$. The method used for Pu-238 and Pu-239 was not used for these isotopes because the values from that method were considerably lower. There are no other data available for comparison with this data.

- The content of $\mathrm{Cm}-244$ in each type of glass was calculated by

$$
R(\mathrm{Cm}-244)_{i}=\left[\mathrm{m}(\operatorname{Group} B)_{i} / \mathrm{m}(\operatorname{Group} B)_{D B}\right] \cdot R(\mathrm{Cm}-244)_{D B}
$$

where $R$ is the activity in curies/canister; $i$ refers to Batch $i$; $m$ (Group B) denotes the mass flow of Group B; and DB denotes the design-basis. Comparison of the resulting values to the Tank 51 value suggests that the projected values are highly conservative. The content of Cin-244, as a member of Group B, could have been calculated in the same manner as described for $\mathrm{Zr}-93$. This calculation yielded values which were four orders of magnitude below the design-basis value, and two orders of magnitude below the Tank 51 value. For this reason, that method was not used to obtain the values in Table 5 .

\section{TOTAL OUANTITIFS OF RADIONUCLIDFS FOR FACH BATCH}

The total quantity of each radionuclide for each Batch is listed in Table 6. These were obtained by multiplying the values in Table 5 by the projected number of canisters for that Batch (910 for Batch 1, 987 for Batch 2, 1002 for Batch 3, and 751 for Batch 4).11 Totaling these values leads to the conclusion that the DWPF will have vitrified $2.2 \cdot 10^{8}$ curies at time of production of these four Batches.

Some of the totals provide checks of the data. For example, the $9800 \mathrm{Ci}$ of Tc-99 compares favorably to the total of 23,700 Ci currently in the Tank Farm, when the partitioning of Tc between salt and sludge is taken into account. The amounts of Sr-90 and $\mathrm{Cs}-137$ are somewhat lower than those reported in the Integrated Data Base, 5 but are not unreasonable considering that they represent only the first four batches of material to the DWPF, and not all of the material currently in the Tank Farm. 
TABIE 5

PBOJECTFD RADIONUCITDF INVYHNTORIFS OF CANISTHFRS FROM BATCHES 1 - 4 (at time of production)

Radionuclide

$$
\begin{aligned}
& \mathrm{N}-59 \\
& \mathrm{Ni}-63 \\
& \mathrm{Se}-79 \\
& \mathrm{Sr}-90 \\
& \mathrm{Zr}-93 \\
& \mathrm{Nb}-93 \mathrm{~m} \\
& \mathrm{~T} \mathrm{C}-99 \\
& \mathrm{Pd}-107 \\
& \mathrm{Sn}-126 \\
& \mathrm{Cs}-135 \\
& \mathrm{Cs}-137 \\
& \mathrm{Sm}-151 \\
& \mathrm{Th}-230 \\
& \mathrm{~Np}-237 \\
& \mathrm{U}-234 \\
& \mathrm{U}-238 \\
& \mathrm{Pu}-238 \\
& \mathrm{Pu}-239 \\
& \mathrm{Pu}-240 \\
& \mathrm{Pu}-241 \\
& \mathrm{Pu}-242 \\
& \mathrm{Am}-241 \\
& \mathrm{Am}-243 \\
& \mathrm{Cm}-244
\end{aligned}
$$

TOTAL

\section{Amount (Ci/canister)}

\section{Batch 1}

Batch 2

Batch 3

2.08E-02

1.20E-02

Batch 4

1. 05E-02

$2.59 \mathrm{E}+00$

1. $49 \mathrm{E}+00$

2. 81E-02

1. $31 \mathrm{E}+00$

2. 13E-01

1. $63 \mathrm{E}-01$

3. $49 \mathrm{E}+00$

1. $55 \mathrm{E}-01$

5. $09 E+04$

$4.08 \mathrm{E}+04$

3. $18 \mathrm{E}-01$

$7.53 \mathrm{E}+03$

$9.21 \mathrm{E}+00$

$5.28 \mathrm{E}+00$

$2.83 E+04$

4. $66 \mathrm{E}+00$

8.11E-02

4. $65 \mathrm{E}-02$

1. $24 \mathrm{E}+01$

4. 10E-02

$3.16 \mathrm{E}+00$

1. $81 \mathrm{E}+00$

1.09E-01

$2.01 E+00$

1. 32E-02

1. $08 \mathrm{E}-02$

$4.02 \mathrm{E}+00$

6.09E-03

5. $89 \mathrm{E}-01$

3. 38E-01

2. $30 E-02$

2. $98 \mathrm{E}-01$

$6.21 \mathrm{E}-02$

$4.54 \mathrm{E}-02$

7. $94 \mathrm{E}-01$

1. $11 \mathrm{E}-01$

2. $71 E+04$

1. $98 \mathrm{E}+04$

2. 57E-02

4. $85 \mathrm{E}+04$

1. $04 \mathrm{E}+03$

$5.94 \mathrm{E}+02$

1. $12 \mathrm{E}+04$

5. $24 \mathrm{E}+02$

2.11E-06

2. $90 \mathrm{E}-06$

1. $39 E+03$

4. $83 \mathrm{E}-07$

1. $28 \mathrm{E}-01$

7. $35 \mathrm{E}-02$

7. $28 E-07$

6. $49 \mathrm{E}-02$

3. $60 \mathrm{E}-02$

4. $94 \mathrm{E}-02$

1. $73 \mathrm{E}-01$

8. 22E-03

1. $10 \mathrm{E}-02$

1. $52 \mathrm{E}-02$

1. $24 \mathrm{E}-02$

$2.53 E-03$

1. $43 \mathrm{E}+02$

9. $22 \mathrm{E}+01$

3. $80 E-03$

3. $88 E+01$

$4.64 \mathrm{E}+00$

$5.13 \mathrm{E}+00$

1. $90 \mathrm{E}+02$

$2.03 E+00$

3. $12 \mathrm{E}+00$

3. $45 \mathrm{E}+00$

3. $26 E+00$

1. $36 \mathrm{E}+00$

5. $67 \mathrm{E}+01$

1. $61 \mathrm{E}+02$

2. $19 E+00$

7. $38 \mathrm{E}+00$

4. 39E-03

4. 85E-03

4. $20 E+02$

1. $92 \mathrm{E}-03$

9. $60 \mathrm{E}+00$

$5.50 \mathrm{E}+00$

3. $09 \mathrm{E}-03$

4. $85 \mathrm{E}+00$

3. $60 \mathrm{E}-01$

$2.06 \mathrm{E}-01$

1. $29 \mathrm{E}+01$

1. $82 \mathrm{E}-01$

2. $02 E+02$

1. $16 \mathrm{E}+02$

4. 85E-01

1. $02 \mathrm{E}+02$

5. $67 \mathrm{E}+04$

$7.95 E+04$

$6.16 E+04$

4. 17E+04

\section{SOURCFS OF FRROR IN SINGTIE CANISTER VAIUTAS}

The projected inventories in Table 5 are subject to several sources of uncertainty. These include the errors in the calculations, potential Tank Faim process variations, and DWPF process variations. Of these, the first two are the most significant.

The errors in the calculations vary for each radionuclide. Based 


\section{THBIE 6}

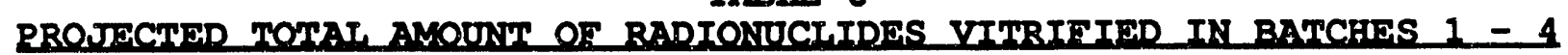

(at time of production)

Radienuclide

\begin{tabular}{|c|c|c|c|c|c|}
\hline & Batch 1 & Batch 2 & Batch 3 & Batch 4 & TOTAT \\
\hline $\mathrm{Ni}-59$ & $9.60 \mathrm{E}+00$ & $2.06 E+01$ & $1.20 \mathrm{E}+01$ & $2.11 E+01$ & $6.32 \mathrm{E}+01$ \\
\hline $\mathrm{Ni}-63$ & $1.19 \mathrm{E}+03$ & $2.56 \mathrm{E}+03$ & $1.49 E+03$ & $2.62 E+03$ & $7.86 \mathrm{E}+03$ \\
\hline$S e-79$ & $1.41 \mathrm{E}+02$ & $2.10 E+02$ & $1.63 E+02$ & $2.39 E+02$ & $7.54 \mathrm{E}+02$ \\
\hline $\operatorname{sr}-90$ & $6.85 E+06$ & $5.02 E+07$ & $4.09 E+07$ & $2.13 E+07$ & $1.19 \mathrm{E}+08$ \\
\hline $2 r-93$ & $4.24 \mathrm{E}+03$ & $9.09 E+03$ & $5.29 E+03$ & $9.32 E+03$ & $2.79 \mathrm{E}+04$ \\
\hline $\mathrm{Nb}-93 \mathrm{~m}$ & $3.73 E+01$ & $8.00 E+01$ & $4.66 E+01$ & $8.20 E+01$ & $2.46 \mathrm{E}+02$ \\
\hline $\mathrm{TC}-99$ & $1.83 E+03$ & $3.12 \mathrm{E}+03$ & $1.81 E+03$ & $3.02 E+03$ & $9.78 \mathrm{E}+03$ \\
\hline$P d-107$ & $5.54 E+00$ & $1.31 E+01$ & $1.08 \mathrm{E}+01$ & $1.73 E+01$ & 4. $67 \mathrm{E}+01$ \\
\hline $5 n-126$ & $2.71 E+02$ & $5.82 E+02$ & $3.39 E+02$ & $5.96 \mathrm{E}+02$ & $1.79 \mathrm{E}+03$ \\
\hline$C s-135$ & $1.01 E+02$ & $6.13 E+01$ & $4.55 E+01$ & $1.93 E+01$ & $2.27 E+02$ \\
\hline$C s-137$ & $4.41 E+07$ & $2.67 E+07$ & $1.98 E+07$ & $8.41 E+06$ & $9.91 \mathrm{E}+07$ \\
\hline $\mathrm{Sm}-151$ & $4.77 E+05$ & $1.02 \mathrm{E}+06$ & $5.95 E+05$ & $1.05 \mathrm{E}+06$ & $3.14 \mathrm{E}+06$ \\
\hline Th -230 & $4.40 E-04$ & $2.09 E-03$ & $2.91 E-03$ & $5.47 \mathrm{E}-04$ & $5.98 \mathrm{E}-03$ \\
\hline$N p-2.37$ & $5.91 E+01$ & $1.27 E+02$ & $7.37 \mathrm{E}+01$ & $1.30 \mathrm{E}+02$ & $3.89 \mathrm{E}+02$ \\
\hline $\mathrm{U}-234$ & $7.48 \mathrm{E}+00$ & $3.55 E+01$ & $4.95 E+01$ & $9.31 E+00$ & $1.02 \mathrm{E}+02$ \\
\hline$U-238$ & $2.30 \mathrm{E}+00$ & $1.09 E+01$ & $1.52 \mathrm{E}+01$ & $2.86 \mathrm{E}+00$ & $3.13 E+01$ \\
\hline$P u-2.38$ & $3.53 E+04$ & $1.42 \mathrm{E}+05$ & $9.23 E+04$ & $1.43 E+05$ & $4.12 \mathrm{E}+05$ \\
\hline $\mathrm{Pu}-239$ & $1.85 \mathrm{E}+03$ & $4.58 E+03$ & $5.14 \mathrm{E}+03$ & $2.45 \mathrm{E}+03$ & $1.40 \mathrm{E}+04$ \\
\hline$P u-240$ & $1.24 \mathrm{E}+03$ & $3.08 E+03$ & $3.46 \mathrm{E}+03$ & 1. $65 \mathrm{E}+03$ & $9.43 E+03$ \\
\hline$P u-241$ & $6.71 E+03$ & $5.60 \mathrm{E}+04$ & $1.61 E+05$ & $3.16 \mathrm{E}+05$ & $5.40 \mathrm{E}+05$ \\
\hline$P u-242$ & $1.75 E+00$ & $4.33 E+00$ & $4.86 \mathrm{E}+00$ & $2.32 E+00$ & $1.33 E+01$ \\
\hline$A m-241$ & $4.42 E+03$ & $9.47 E+03$ & $5.51 E+03$ & $9.70 E+03$ & $2.91 E+04$ \\
\hline$A m-243$ & $1.66 \mathrm{E}+02$ & $3.55 E+02$ & $2.07 \mathrm{E}+02$ & $3.64 \mathrm{E}+02$ & $1.09 \mathrm{E}+03$ \\
\hline $\mathrm{Cm}-244$ & $2.32 \mathrm{E}+04$ & $2.00 \mathrm{E}+05$ & $1.16 \mathrm{E}+05$ & $1.02 \mathrm{E}+05$ & $5.115+0.5$ \\
\hline TOTAL & $5.16 E+07$ & $7.84 \mathrm{E}+07$ & $6.17 \mathrm{E}+07$ & $3.13 E+07$ & $2.23 E+08$ \\
\hline \multicolumn{6}{|c|}{$\begin{array}{l}\text { on the limited comparisons reported above, the projected invento- } \\
\text { ries agree with other reported values within about } 25 \% \text { for the } \\
\text { more concentrated radicnuclides, but only to within a factor of } \\
\text { 100 for more dilute, species (e.g., cm-244). Thus, at least for } \\
\text { the dilute radionuclides, this is the dominant source of uncer- } \\
\text { tainty. }\end{array}$} \\
\hline
\end{tabular}

Potential variations in Tank Farm processing are probably the 
largest source of uncertainty in the inventories of individud canisters for the more concentrated radionuclides. As an example, a canister containing the design-basis waste glass would contain $95 \mathrm{kCi} / c a n i s t e r$ of reportable radionuclides, while the first glass produced by the DWPF will contain approximately $57 \mathrm{kCi} /$ canister, at time of production. Thus, if younger waste is mixed with the older waste in Batch 1, the inventory per canister would significantly increase. Because of the limited number of Tank Farm samples which have been analyzed for these radionuclides, it is not possible to quantify this potential variability. However, the magnitude of this increase is probably bounded by the maximum variation in analytical values for any individual radionuclide in Tank Farm samples, which is approximately a factor of ten. Thus, potential variations in Tank Farm processing are large sources of uncertainty in the inventory of individual canisters, but are difficult to quantify.

The uncertainty in the projected inventories per canister due to variations in the DWPF process is easily quantified, but probably much less significant than the other uncertainties. Pilot plant experience indicates the relative variability for the DWPF process should be on the order of $20 \%$, including batch-to-batch variations and variations in canister filling. Compared to the large uncertainties due to errors in the calculations and potential variations in Tank Farm processing, DWPF process variations appear of minor importance.

\section{SOURCFS OF IRROR IN TOTAT ACTIYITY VITRTETFD}

The total activity vitrified in each batch is subject to the same errors identified above as well as errors in the projected number of canisters for each sludge batch. The assumed solids to volume ratio is most likely the largest contributor to the error in this case. As is discussed in reference 11, the total uncertainty in the number of canisters may be as high as $60 \%$.

\section{REFFRFNCFS}

1. Office of Civilian Radioactive Waste Management, Waste Acceptance Preliminary Specifications for Vitrified High-Level Waste Forms, Draft for approval, June, 1991.

2. Defense Waste Processing Facility, DWPF Waste Form Compliance Plan, WSRC SW4-6, Revision 0, March, 1990.

3. Defense Waste Processing Facility, Basic Data Report, Revision 92, DPSP-80-1033 (1988).

4. B. A. Hacker, "Radionuclides to be Reported for DWPF Waste Accef'-ance," DPST-86-789, November 19, 1986.

5. Oak Ridge National Laboratory, Integrated Data Base for 1991:

o. s. Spent FueI and Radioactive waste Inventories, Rrojections, 
and Characteristics, Revision 7, USDOE Report RW-0006, Washington, DC (1991).

6. J. R. Fowler, "Major Waste Processing Streams for Waste Glass from Sludge Batch 1," WSRC-RP-89-129, April 21, 1989.

7. J. R. Fowler, "Major Waste Processing Streams for Waste Glass from Sludge Batch 2," WSRC-RP-89-130, April 21, 1989.

8. J. R. Fowler, "Major Waste Processing Streams for Waste Glass from Sludge Batch 3," WSRC-RP-89-131, April 21, 1989.

9. J. R. Fowler, "Major Waste Processing Streams for Waste Glass from Sludge Batch 4," WSRC-RP-89-132, April 21, 1989.

10. T. E. Pate, Savannah River Site Radioactive Liquid Waste Forecast - 1990, WSRC-RP-90-589, June 29, 1990.

11. M. J. Plodinec, Estimates of DWPF Canister Production, WSRCTR-91-648, December 6, 1991.

12. F. W. Walker, D. G. Miller, and F. Feiner, Chart of the Radionuclides, 13th edition, General Electric Co., 1984.

13. Westinghouse Savannah River Co., Accountability Standard Decay and Activity Values, USDOE Document WSRC 7Q1-7, November 1 , 1991. 

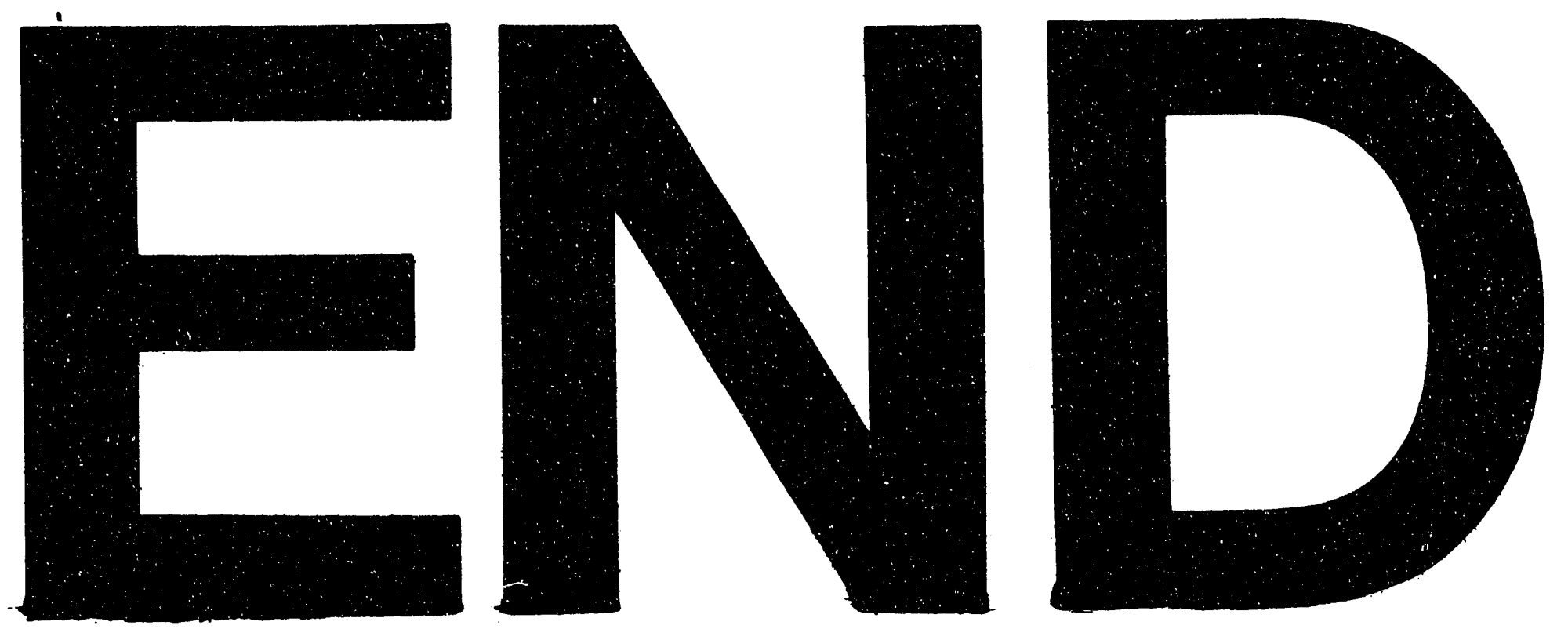

$x$
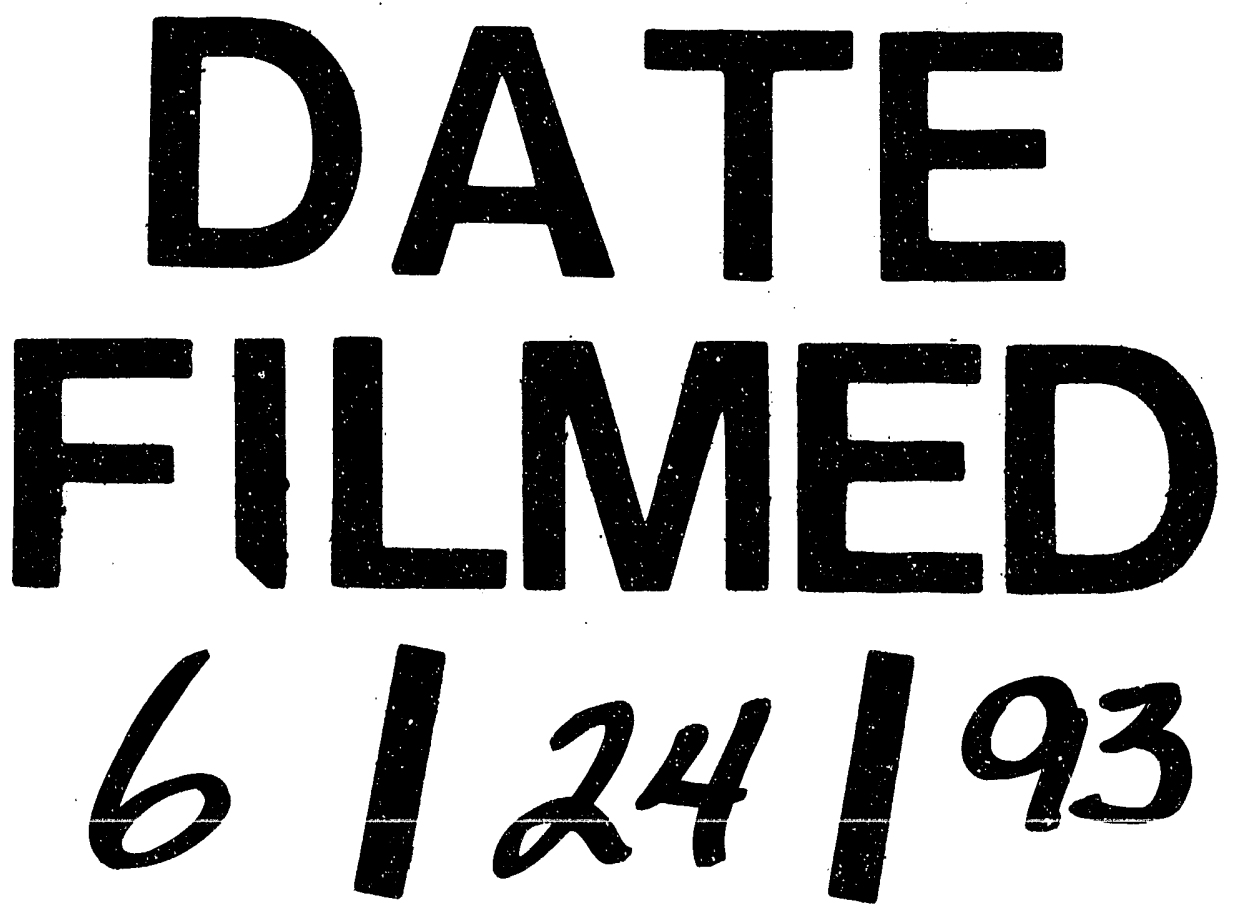
